\title{
MODERNIZATION OF SOLID WASTE CRUSHING EQUIPMENT
}

\section{Bondarenko}

Research Institute "Ukrainian Research Institute of Ecological Problems"

vul. Bakulina, 6, Kharkiv, 61166, Ukraine. E-mail: i.v.bondarenko@ukr.net

Purpose. In the light of the urgency of improving energy saving of the technological processes of solid waste management in Ukraine, the purpose of the work is modernization of equipment for secondary raw materials processing. Methodology. A review and comparative analysis of the modern level of technical support of crushing processes in the sphere of waste management have been conducted. Originality. Taking into account the main requirements of the branch-specific regulatory legal acts, principles and planned activities of the National Waste Management Strategy, as well as analysis of the shortcomings of the special equipment already known, a principally new design of a Crushing Unit with Gravity-Pneumatic Actuator for using alternative energy resources during the operation of the necessary technological equipment of secondary raw materials management systems has been proposed. Practical value. The scheme of the reference apparatus we have developed relates to devices for crushing with rotating knives driven by volumetric displacement power plants, can be used in systems while creating a significant amount of solid fractions of waste of a high bulk density, enables generation and accumulation of electric energy required for its work, in which it uses the weight of raw materials to be processed as a drive force, as well as reduces the number of necessary external equipment involved in processing. The energy generated by the proposed apparatus can be accumulated for further implementation of technical support at other stages of collection, transportation, storage, utilization or recovery of waste. The work provides for operating practices and variants of the unit design to carry out the cleaning processes for its working surfaces and to normalize operation during emergencies. In order to improve the energy saving level of processes for crushing equipment transportation, a self-propelled modification of the proposed apparatus has been developed that uses generated electric energy to supply with electricity the electric motors of single or combined mobile platforms while delivering the equipment to the place of operation. Conclusions. The presented materials can be effectively used to improve the ecological-economic efficiency of exploiting the material-technical base of systems for sanitary cleaning of settlements, to reduce the specific consumption of electric energy required when processing solid waste and can be used for modernization and functioning of a network of mobile crushing equipment. References 23, tables 1, figures 7.

Key words: waste, processing, crushing, energy saving, equipment, cleaning

\section{І. В. Бондаренко}

\section{МОДЕРНІЗАЦІЯ ОБЛАДНАННЯ ДЛЯ ДРОБЛЕННЯ ТВЕРДИХ ВІДХОДІВ}

Науково-дослідна установа «Український науково-дослідний інститут екологічних проблем» вул. Бакуліна, 6, м. Харків, 61166, Україна. E-mail: i.v.bondarenko@ukr.net

Розглянуто актуальність проблеми енергозбереження при обробці твердих відходів та проаналізовано сучасний рівень технічного забезпечення процесів дроблення у сфері поводження з відходами. Із урахуванням основних вимог нормативних, галузевих законодавчих актів, принципів і планованих заходів Національної стратегії управління відходами в Україні, та аналізу недоліків відомого спеціального устаткування, запропонована принципово нова конструкція дробильного агрегату з гравітаційно-пневматичним електроприводом для використання альтернативних енергоресурсів при експлуатації необхідного технологічного обладнання систем управління вторинною сировиною. Розроблено схему базового апарату, яка відноситься до пристроїв для дроблення ножами, що обертаються і приводяться у дію силовими установками об'ємного витіснення, та може використовуватися в системах з утворенням значної кількості твердих фракцій відходів великої насипної щільності, дає можливість генерації та акумуляції потрібної для його роботи електроенергії, використовуючи при цьому в якості привідного зусилля вагу матеріалів, які обробляються, та скорочує кількість зовнішнього устаткування, що залучається до процесу переробки. Генерована пропонованим апаратом енергія може бути накопичена для подальшої реалізації роботи технічного забезпечення на інших стадіях збору, транспортування, зберігання, утилізації чи рекуперації відходів. У роботі передбачено технологічні режими функціонування і варіанти конструкції агрегату для здійснення процесів очищення його робочих поверхонь та нормалізації експлуатації при аварійних станах. 3 метою підвищення рівня енергозбереження процесів транспортування дробильного обладнання розроблено самохідну модифікацію запропонованого апарату, що використовує генеровану ним електроенергію для живлення електродвигунів одиночних чи з'єднаних мобільних платформ при доставці обладнання до місця роботи. Викладені матеріали можуть бути застосовані для підвищення еколого-економічної ефективності експлуатування матеріально-технічної бази систем санітарної очистки населених пунктів, зниження питомих витрат необхідної електроенергії, і може бути використано для модернізації та функціонування мережі мобільного дробильного обладнання.

Ключові слова: відходи, переробка, дроблення, енергозбереження, обладнання, очистка.

PROBLEM STATEMENT. According to the Law of Ukraine "On Waste", one of main directions of the state policy regarding the realization of the principles of protection of the environment and human health from the negative influence of waste is contribution to the maximum possible utilization of used materials by direct reutilization or alternative use of their valuable resources, facilitation of the comprehensive use of raw 
material resources, and economical use of energetic resources [1]. However, the modern system for used materials management in the country is characterized by an extremely low efficiency and the tendency of deepening crisis. The volume of waste accumulated on the territory of the country is estimated at 36 billion tons. At the same time, according to the data of the State Statistics Service of Ukraine, the amount of danger class I-III waste utilized was 439 thousand tons in 2013, 345 thousand tons in 2017 , after decreasing by $518,29 \%$ as compared to 1994 (2,133,1 thousand tons). Remarkably, only used automobile tires (solid waste of danger class IV, which can form toxic compounds of sulphur of danger class III, biphenyl, anthracene, pyrene and other harmful substances in case of improper storage and contact with other SHW components, external natural environment and acid precipitation at places of their accumulation), according to specialists, make up virtually 300-400 thousand tons per year.

Processing of used materials includes different levels. A significant part of waste consists of their solid fractions, including, for example, remains of raw materials, materials and semi-products, products of physical and chemical processing of raw materials, products of mining and enrichment of minerals, household waste, substances received after wastewater cleaning, etc. For rational treatment of this waste, it is important to crush it for its further industrial use and processing. One of the regressive factors of the problem of the low efficiency of solid used materials management is significant energy consumption during the majority of the technological processes of their treatment (for example, specific consumption of electric energy for crushing $1 \mathrm{t}$ of secondary raw materials is approximately $10 \mathrm{~kW}$, whereas for crushing only wooden waste this index is $82 \mathrm{~W} / \mathrm{kg}$ ).

According to the National Waste Management Strategy [2], among the major special activities and ways to improve the efficiency of the domestic waste treatment systems are modernization of the materialtechnical base of economic subjects for the reuse of natural resources, processing and utilization of waste, creation of regional facilities for accepting and storing used materials, with intermediate sorting and crushing by crushing and screening units, as well as functioning of a network of mobile crushing equipment.

In the context of the difficult current economic situation and energetic dependence of Ukraine, one of the main ways to comply with the requirements to create specialized elements of infrastructure is to improve the energy saving degree of the branch-specific technical support during the required technological processes. According to the main provisions of the Law of Ukraine "On Energy Saving", one of the main principles of the state policy in this sphere is the priority of energy saving requirements during the implementation of economic, managerial or other activities connected with mining, processing, transportation, storing, producing and use of fuel and energy resources.

In DBN "Composition and Content of the Scheme of Sanitary Cleaning of a Settlement", it is noted that waste treatment systems are developed according to the Law of Ukraine "On Waste"; while providing for the use of advanced technologies, technical solutions, technological equipment conforming to the environment protection and sanitary-hygienic requirements and making the influence of harmful factors on the environment and human health impossible.

Taking into account the significant obsolescence of existing branch-specific technical means, it all makes necessary their modernization and development of new special energy-saving equipment to improve the ecological safety and economic profitability of the modern technical support of such major problematic processes of the functioning of waste treatment systems as crushing solid secondary materials.

The problems of management, development and modernization of waste treatment systems in Ukraine are presented in detail in the works of such scientists as: O.S. Parfeniuk; M.Y. Krasniansky; S.I. Antoniuk; V.V. Vambol; M.S. Maliovany; V.M. Shmandiy [3-9] and others. However, certain aspects of improvement of the energy saving level of certain specialized technological processes still need additional research.

Today the market of specialized equipment in the sphere of waste treatment [10], especially technical support of crushing processes [11], is rather developed. Nevertheless, experts identify a range of significant shortcomings during the use of known basic types of crushing machines, among which the most problematic are: high energy consumption; complicated maintenance; fast wear and tear of hammers, plates and other elements; pollution of taper openings; clogging of the bar grating - when crushing wet plastic materials; high cost of structural elements [12-14].

While analyzing information from the international patent information bases about the state of the art in this sphere of usage, it is appropriate to distinguish such well-known technical solutions as, for example, a "tire crushing plant" [15] designed for crushing frozen polytypical tires and objects from brittle polysynthetic and natural materials that has a main crushing device with supporting structures, where the crushing process takes place due to the use of couples of coaxial pneumatic cylinders identical by design that are rigidly fixed on the supporting metal structures of the receiving vulcunizate bunker and oppositely enveloped by front covers, between which and the pushing pistons there are returning pressure springs that are coaxial and concentric to the pneumatic cylinder rods that can also have coaxial and concentrically placed external watercooling housings with discharge openings. The following shortcomings of this device can be identified: the absence of system elements of autonomous electric power supply, which makes the whole unit completely dependent on the external functioning environment; the necessity of preliminary preparation of initial raw materials (for example, cryogenic processing of rubber technical products) for increasing the brittleness of materials, which results in energy consumption during preparatory processes; significant energy consumption during the industrial process of crushing; the necessity of using water for cooling structural elements, which can be inadmissible under the conditions of exhaustion of natural resources; high risk of failure of certain 
device elements (for example, rods and pistons) as a result of creating abrupt kinetic overloads, which decreases the reliability of the machine during its operation; increasing risk of traumatism of the service staff due to the use of explosive waves; the necessity of involving additional items of equipment. Altogether, the indicated shortcomings of this technical solution cause its low ecological and economic efficiency. Among the specialized equipment we can distinguish such inventions as: a "crushing and finely dispersed materials production system" [16] that refers to units for crushing and separation by both the fraction composition and density of solid and super-solid materials and can be used for crushing in particular polymetallic ores, slags, coal slurries, limestone, chalk and any other solid, super-solid and viscous materials; a "mill for crushing materials" [17], which refers to the field of crushing various materials and can be used in mining, construction, energy and other branches of industry; an "impact crushing method" [18] relating to the methods of grinding, in particular to the methods of impact crushing of bulk materials, and can be used in mining, ore mining, construction and other branches of industry where grinding of bulk materials is necessary; a "method and apparatus for crushing worn tires" [19] relating to methods and devices for crushing and shredding tires for the efficient processing and reuse of rubber materials by separating the iron and steel components built into the tires; a "crushing rotor" [20] relating to rotors used in crushing machines; a "method for crushing materials in an inertial cone grinder" [21], intended for crushing materials, in particular metal or diamond-bearing ores; etc.

The common disadvantages of these technical solutions include large energy consumption for the production process, the need to use external power units, supply of external energy, which significantly reduces the efficiency and environmental friendliness of the equipment.

The goal of this work is to increase the ecological and economic efficiency of waste management systems through the development of energy-saving equipment for crushing of solid waste with the possibility of creating a network of stationary and mobile crushing plants as part of the technical support of schemes of sanitary cleaning of settlements.

The work is relevant in view of the urgent need of development and modernization of the technical support of solid waste treatment processes, due to the obsolescence of existing equipment, excessive accumulation of waste materials, and the main provisions of the National Management Strategy [2].

The novelty of this work lies in the fundamentally new approach to designing power plants to ensure the energy-autonomous operation of the crushing unit in the processing of solid waste with application of a gravitypneumatic actuator with the possibility of generation and accumulation of electric energy for its use in further industrial processes.

MATERIAL AND RESULTS. Given the above shortcomings of existing technological equipment for the implementation of grinding processes (in particular high specific energy consumption), as one of the major stages of solid waste processing, the need to prioritize this aspect of the problem becomes apparent.

In this regard, a fundamentally new specialized scheme of the apparatus "Crushing Unit with GravityPneumatic Actuator" [22] has been proposed, which is based on the principle of operation of the device "M-RA-power column" [23], which refers to generators displacing the current circulating medium and can be used to produce environmentally friendly mechanical force. Schematic diagram of the crushing unit is shown in Figure 1.

The proposed device relates to devices for crushing waste with rotating knives using power plants of volumetric displacement and can be used in technological schemes with the formation of significant amounts of solid waste of large bulk density.

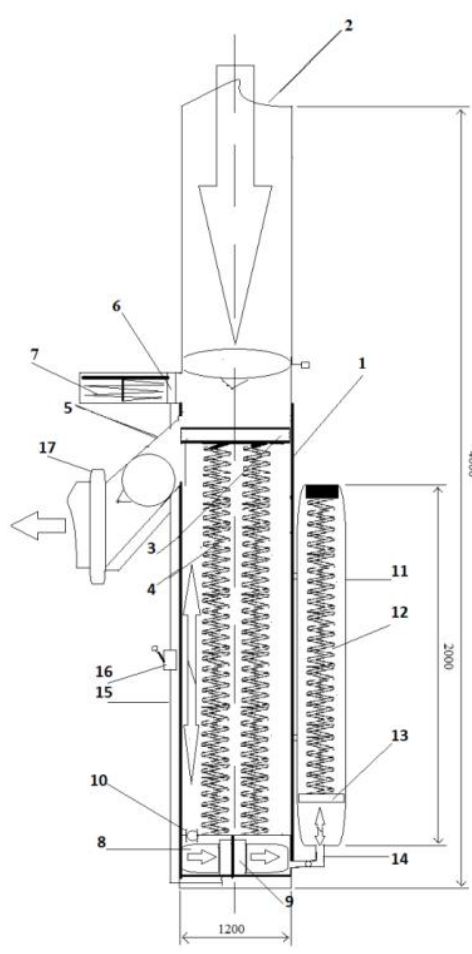

Figure 1 - Schematic diagram of the Crushing Unit with Gravity-Pneumatic Actuator (reference version):

1 - body; 2 - charge pipe; 3 - bottom-piston; 4 - central spring; 5 - discharge pipe;

6 - electric motor; 7 - knife; 8 - turbine blade;

9 - generator; 10 - startup hole; 11 - pneumatic accumulator tank; 12 - spring of tank $11 ; 13$ - piston of tank $11 ; 14$ - pneumatic tube; 15 - power cable; 16 - switch; 17 - compressor

Accordingly to the invention, the basic structure of the crushing unit includes a cylindrical body in which a bottom-piston is placed with the possibility of reciprocating motion and rigidly connected to a system spring; a charge pipe rigidly connected to the cylindrical body, which is equipped with a semi-automatic charge valve; and a discharge pipe pivotally connected to the body of the actuating device (knife) and its motor coupled with an air-driven electric generator with an electric cable equipped with a control switch; a pneumatic mechanical accumulation tank rigidly connected to the cylindrical body through a pneumatic pipe line. 
In the crushing unit, minimization of energy consumption during the grinding of waste, reduction of necessary additional equipment and improvement of the efficiency and environmental friendliness of the crushing process is achieved due to the fact that the bottompiston displaces compressed air from the machine body into the drive compartment under the influence of the weight of the waste and compresses the system spring, thus accumulating their kinetic energy, which actuates the electric generator (by generating an electric pulse), after which the gaseous medium flows and accumulates in the pneumatic mechanical tank with the possibility of returning to the main body via the drive compartment, re-starting the generator, which happens due to the effect of back suction of the air during the lifting of the bottom-piston in the process of grinding and automatic removal of the material under treatment from the crushing area with a built-in compressor.

The device contains the bottom-piston 3 located in the cylindrical body 1 , connected with the spring 4 (Fig. 1). The body 1 is rigidly connected with the charge pipe 2 and the discharge pipe 5 provided with a valve and the electrically driven compressor 17 . The body also has a side "pocket" that contains the electric motor 6 and the actuating device 7. In its lower part, the cylinder 1 is equipped with the drive compartment, which includes the electric generator 9 fitted with blades 8 . The generator 9 is connected to the motor 6 and the compressor 17 via the cable 15 equipped with the switch 16 . The device body is connected with the drive compartment via the hole 10 . The pneumatic mechanical accumulation tank 11 includes the piston 13 mounted on the spring 12 . The tank 11 is connected to the drive compartment through the valve pipe 14 .

Operation of the device is described below. Proceeding through the charge pipe 2 equipped with a one-way valve, the secondary raw material fills the interior space of the body 1 while exerting influence on the bottompiston 3 , thus reducing its level on the vertical axis and compressing the spring 4 . As a consequence, there occurs displacement of the compressed air located under the bottom-piston 4 into the drive compartment through the hole 10 (which can be equipped with a nozzle to increase the pneumatic force), contributing to the rotation of the blades 8 and the startup of the generator 9. The initial pressure level of compressed air (pumped into the apparatus during its production through the service pipe), and therefore the maximum capacity of the unit can vary based on the strength of the basic material from which the body 1 is made and depending on the required capacity for the grinding of certain type of waste.

Electricity produced by the generator is accumulated by an integrated battery with the possibility of further use for the operation of the proposed device. After going through the drive compartment, the compressed air is supplied to the pneumatic mechanical accumulation tank 11 via the pipe 14 fitted with a valve. The gradual filling of the tank exerts influence on the piston 13 and compresses the spring 12 (Fig. 1). Also, two-cycle loading of raw materials is possible, where the charge pipe 2 is completely filled, after which there occurs the opening of the semi-automatic valve located in the body of the device, which causes a momentary pressure of the weight of raw material on the piston 3 . The loading of the machine can be continued. After the maximum loading of the unit with raw materials and the maximum lowering of the bottom-piston 3 , the battery built in the generator 9 is automatically switched (for example, using an electric relay) into the power supply and electric pulse transmission mode via the cable 15 , the motor 6 and the compressor 17. The motor 6 starts the actuating device 7. To prevent mechanical damage, the actuating device can be placed in the side "pocket" of the body 1 with the possibility of extension into the crushing area.

The actuating device 7 may contain piezoelectric elements 18, blades 19, electrodes for electric pulse sampling 20 and an electric generator 21 (Fig. 2).

Also, the device can have a pneumatic mechanical accumulation coupling 22 located coaxially with the body 1 and a coil spring 23 and an annular piston 24 (Fig. 3).

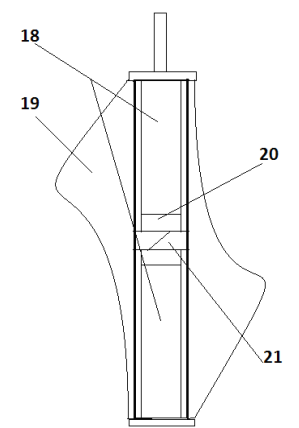

Figure 2 - Scheme of the actuating device (knife) with the function of background power generation:

18 - piezoelectric crystal plate; 19 - blades; 20 - electric generator; 21 - drive shaft

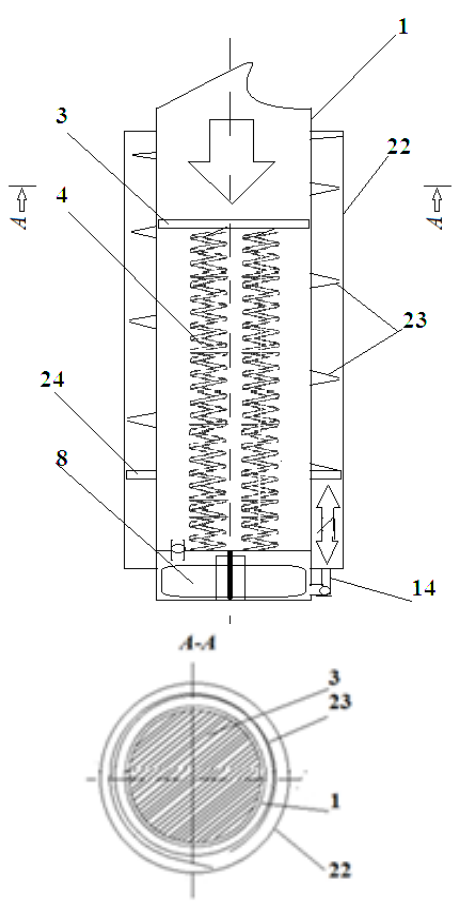

Figure 3 - Location diagram of the pneumatic mechanical accumulation coupling (in longitudinal and cross sections): 1 - body; 3 - bottom-piston; 4 - central spring; 8 - turbine blade; 14 - pneumatic tube; 22 - pneumatic mechanical accumulation coupling; 23 - coil spring; 24 - annual piston 
Crushing of raw materials is performed due to the rotation of the extended knife. When actuated, the compressor 17 located in the discharge pipe 5 opens the oneway valve safety valve and gradually removes the crushed fractions of raw materials from the crushing area. As the grinding of materials is performed, the bottom-piston 3 is lifted due to the use of kinetic energy of the springs 4 , with the dosed supply of raw materials to the crushing area. Parallel to the movement of the bottom-piston 3 , the return suction of the compressed air from the tank 11 in the automatic mode occurs due to its passing through the pipe 14 , flowing to the drive compartment, and penetration into the space under the bottom-piston 3, through the hole 10. At the same time, there occurs the rotation of the blades 8 and background electricity generation by the generator 9 , which contributes to the maintenance of power supply of the system elements 6 and 17. In the process of the return suction of compressed air, the spring 12 exerts influence on the piston 13, displacing the gaseous medium from the tank 11. After complete removal of the crushed fractions of raw materials from the crushing area and restoration of the initial level of the bottom-piston 3, the assembly is ready for loading of raw materials. The increase of electricity produced by the generator 9 is directly proportional to the increase in the bulk density of the feedstock. The rotation speed of the actuating device and its cutting force can also be adjusted by additional supply of the process medium (compressed air) into the body 1 or tank 11 with the help of the potential fill neck of the pipe 14 . However, this procedure is not mandatory.

The working process of the crushing unit can be controlled with the switch 16 , by the stopping and restarting of power supply of the elements 6 and 17 .

The design of the proposed device may have a special structure of the actuating device 7. According to one of the embodiments, the knife 7 has a power generating function and has a piezoelectric crystal plate 18 located between the two blades 19. In the center of the piezoelectric crystal plate there are electrodes and the generator 20 aligned with the drive shaft 21 connected to the blades 19 with the possibility of rotation of the latter. During the rotation of the actuating device in this design, the resistance of the raw material mass is used to generate an additional electric pulse. The operation of the knife 7 with concomitant generation of electricity is as follows: after the start of grinding of raw materials, through the propulsion of the actuating device by the motor 6 , the energy of the mechanical overloads that are formed on the blades 19 is transmitted to the piezoelectric crystal plate, which leads to compression of the piezoelectric element and the generation of electric power (there occurs the so-called direct piezoelectric effect). With the help of the electrodes, an electric pulse is supplied to the motor 20 (or battery) with its further use and actuation of the disc supports of the blades 19, thus providing extra cutting force (Fig. 2).

The blades of the actuating device 7 can be made from a material with piezoelectric crystal inclusions, which will increase the impact on the processed material.

Another embodiment of the proposed crushing unit provides that the tank 11 may be made in the form of a pneumatic mechanical accumulation coupling 22 locat- ed coaxially with the body 1 and containing the coil spring 23, as well as the annular piston 24 (Fig. 3). Such an execution of the unit will allow to increase the degree of symmetry of the elements of the device, minimize the risk of mechanical damage during transportation and installation.

For anticipation and prevention of failures in the operation of the unit due to possible wear of the springs 4 and 12 , the piston 13 can be rigidly connected with the override rod 26 that is vertically placed in the tank 11 with the possibility of reciprocating motion coaxially to the spring 12 through the hole in the top of the tank 11 and fitted with brackets 25 (Fig. 4). The brackets are also placed on the side outer surface of the tank 11 to form an emergency ladder.

The rod 26 is operated as follows. In case of insufficient lifting and suction force of the springs 4 and 12 during back suction, the operator of the crushing unit should use the side ladder and climb on it. The weight of the operator's body transmits to the piston 13 an extra squeezing effort that displaces the residual air from the tank 11 into the body 1 , which will help to normalize the functioning of the unit before repairs.

Due to the dimensions and geometric forms of the reference version of the proposed device, the unit (tab. 1) can be used as an architectural element, acting as a support column of an industrial or residential building (for example, workshops for waste recycling and environmentally efficient houses).

Table 1 - Possible ratio of the crushing unit parameters (based on the shredding of solid waste with a bulk density $=0,3 \mathrm{t} / \mathrm{m}^{3}$ ) taking into account the cylindrical shape

of the body of the device for permanent installation

\begin{tabular}{|l|c|}
\hline \multicolumn{1}{|c|}{ Parameter name } & $\begin{array}{c}\text { Value } \\
\text { and dimension }\end{array}$ \\
\hline Total height of the unit & $4 \mathrm{~m}$ \\
\hline $\begin{array}{l}\text { Diameter of the unit body } \\
\text { (excluding the pneumatic } \\
\text { mechanical accumulation } \\
\text { coupling) }\end{array}$ & $1,2 \mathrm{~m}$ \\
\hline Total workload volume & $3,95 \mathrm{~m}^{3}$ \\
\hline $\begin{array}{l}\text { Charge pipe volume } \\
\text { (above the weight valve) }\end{array}$ & $1,92 \mathrm{~m}^{3}$ \\
\hline $\begin{array}{l}\text { Maximum volume of the } \\
\text { dynamic working chamber } \\
\text { (under the weight valve) }\end{array}$ & $2,04 \mathrm{~m}^{3}$ \\
\hline Maximum cyclic load (two cycle) & $1,185 \mathrm{t}$ \\
\hline 1st cycle yield (1/2 cycle) & $592 \mathrm{~kg}^{2}$ \\
\hline $\begin{array}{l}\text { Area of the working surface } \\
\text { of the bottom-piston }\end{array}$ & $1,128 \mathrm{~m}^{2}$ \\
\hline
\end{tabular}

During operation, the unit can become contaminated with recycled materials and require maintenance in the form of washing. For cleaning, the unit can be fitted with a hydroregime pipe 27 (Fig. 5).

To perform washing, feed process fluid to the charge pipe 2 (e.g. process water with cleaning solution) until its complete filling with the valve blocked. After the maximum filling, the valve of the pipe 2 is opened manually and the process fluid enters the crushing area, exerting influence on the bottom-piston, thus reducing 
its level and starting the generator 9. At this stage, the pipe 5 closes tightly. Maximum lowering of the bottompiston 3 causes the opening of the taps and valves of the pipe 27 (with the valve locked in the drain pipe 28). Next, process water enters the pipe 2 under the pressure of the bottom-piston 3. After the filling of the pipe, the cycle repeats. Also, the fluid can be removed from the system by opening the tap in the pipe 28 and draining. The result is flushing of the working surfaces of the unit and background generation of electrical energy that can be accumulated to ensure further operation of the unit.

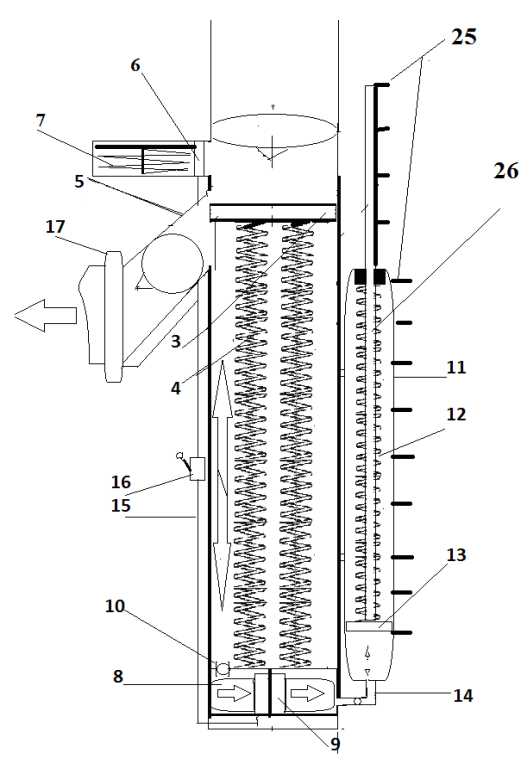

Figure 4 - Location diagram of the override rod: 25 - brackets; 26 - override rod

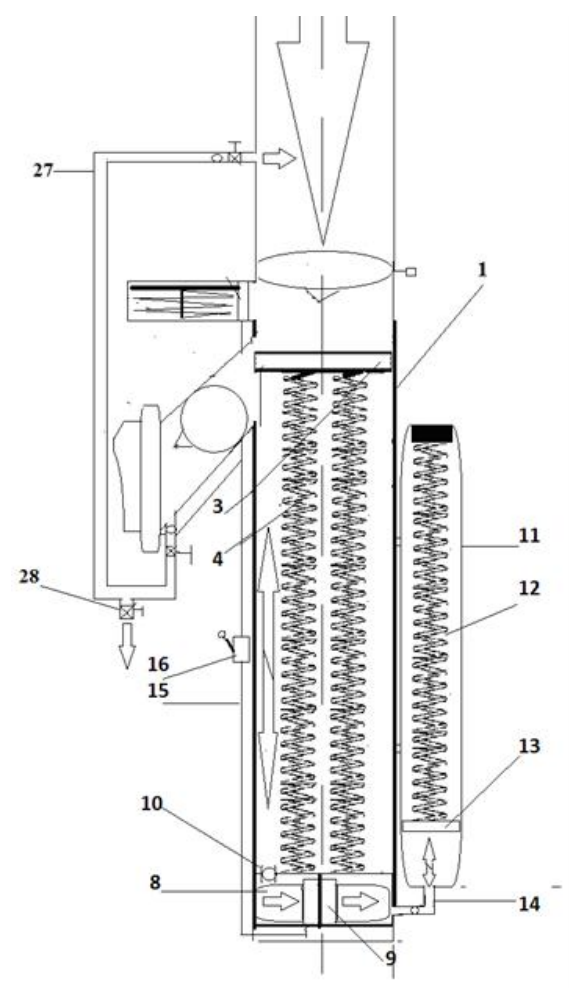

Figure 5 - Diagram of the crushing unit with the hydroregime pipe:

27 -hydroregime pipe; 28 - drain pipe
The energy generated by the device can be accumulated for the implementation of technical support at the following stages of waste processing. Thus, the assembly can be used as a generator in the hydroregime. Given this technical result, and in order to solve the problem of creating an effective network of mobile crushing equipment, a self-propelled modification of the presented device (fig. 6) is proposed.

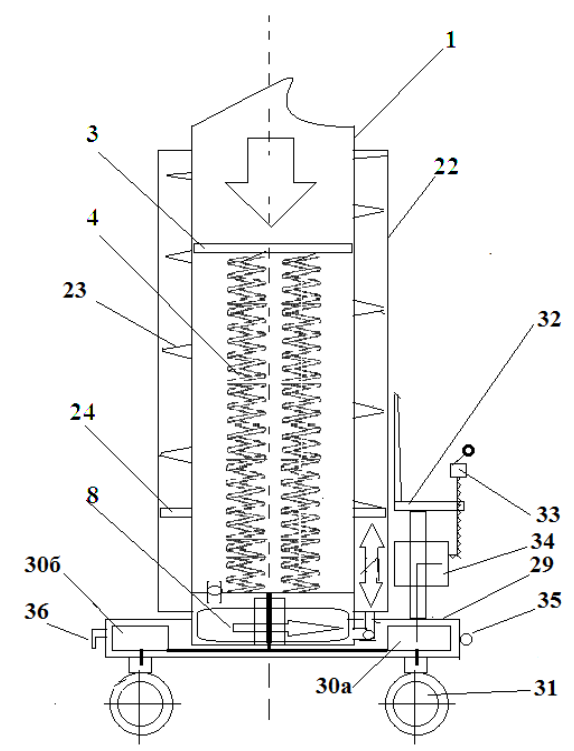

Figure 6 - Diagram of the mobile version of the Crushing Unit with Gravity-Pneumatic Actuator:

29 - transport platform; 30a, 30b - battery-power block; 31 - wheelbase; 32 - operator's seat; 33 - control panel; 34 - control unit; 35 - connecting ring; 36 - connecting hook

The mobile version of the device further comprises a rectangular transport platform 29 on which the lower part of the body 1 is installed and fixed in the provided recess, whereas the generator 9 is electrically connected to the battery-power blocks $30 \mathrm{a}$ and $30 \mathrm{~b}$ containing electric motors and batteries. The blocks 30a and 30b are connected with two (or more) wheel pairs, forming a four-wheel drive wheelbase with the possibility of accumulation and further use of the electricity generated by the crushing unit. The platform 29 is also fitted with the operator (driver) seat, which is provided with a control panel electrically connected to the processor block and the battery-power blocks. The outer body of the platform, on its opposite ends, has connecting elements 35 and 36 for the mechanical coupling of identical structures in order to form a transport column for the energy-efficient movement of large complexes of crushing equipment.

During the movement of the platform 29, both the electricity accumulated during the operation of the proposed unit (or in the hyrdoregime) and the energy produced directly in the process of transportation through the operation of the apparatus in the automatic imitation hyrdoregime can be used. During the movement of the platform, under the operator's control, energy is supplied from the battery-power blocks to the wheelbase, which facilitates the energy autonomous transport of one or several (interconnected) crushing units due to 
their use as pneumatic power plants. After transportation, the crushing equipment is fixed at the place of planned operation and can be used for its intended purpose. After the process of mechanical treatment of waste, the unit is ready for the next transport, which facilitates the creation of an energy efficient network of mobile crushing devices.

The crushing unit can be mounted on regular trailers with the ability to connect to the power plant of the leading electric car for its power supply during equipment transportation.

During transportation of the proposed unit using regular cargo electric vehicles, in order to increase the energy efficiency level of the transportation process it is also possible to use modernized wheels for the vehicle with an additional background electricity generation system (BEG system). As its exploited factor, the BEG system uses aerogravitational overload of car wheels, which occurs during the movement of the vehicle. During the movement of the vehicle along the road, inside the air-containing part of the vehicle wheel under the influence of ram air streams there occurs an increased pressure suitable for background use in the energygenerating converter.

The BEG system (Fig. 7) is a modification of a classic car wheel and contains a replaceable external safety tire 37 mounted on the outer surface of the circulating pneumatic chamber 38 , which is connected through the elastic support points 42 with the hollow bearing body 39 containing a rotary electric generator 40 equipped with pitched blades 43 .
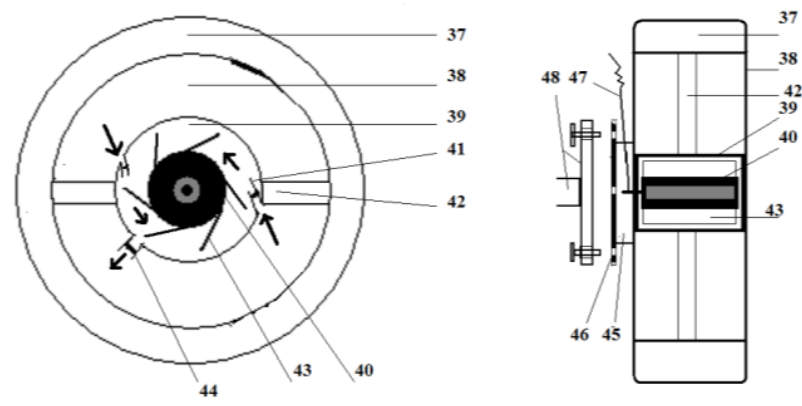

Figure 7 - Schematic diagram of the BEG system car wheel: 37 - external safety tire, 38 - circulating pneumatic chamber; 39 - bearing body, 40 - electric generator, 41 - pitched start tube; 42 - elastic support point; 43 - pitched blade; 44 - outlet tube,

45 - mounting base; 46 - mounting perforated plate; 47 - power transmission cable;

48 - front or rear car axle (fragment)

The body 39 has two (or more) multidirectional pitched start tubes 41 and one (or more) outlet valve tube 44 . The tubes 41 may be equipped with nozzles to increase the pressure. A BEG system wheel also contains a mounting base 45 and a mounting plate 46 rigidly attached to it, for bolted connection with the shaft of the vehicle 48 .

For transmission of the generated electric pulse from the generator 4 to the central power plant of the vehicle, the device has a cable 47 whose passage and location may vary depending on the brand and design of the par- ticular vehicle. The energy transfer can be wireless using existing technologies.

The process of generating an electric pulse (current) by the BEG system is as follows: after the start of movement of the motor vehicle, the pneumatic pressure of compressed air increases in the circulating pneumatic chamber 38, which promotes the jet penetration of the process medium into the bearing body 39 through the pitched start tube 41 .

The pressure of the air jet reinforced by the nozzle drives the generator 40, thus acting on the pitched blades 41 . Due to the multidirectionality of these nozzles, the rotation speed of the generator increases. When the wheel is rotated, the jet flow of air into the bearing body 39 has a permanent nature, resulting in a periodic displacement of air from the body cavity and its exit through the outlet 44 into the circulation chamber 38 . Constantly striving for a state of mechanical standstill, the BEG system facilitates the rotation of the generator regardless of the speed and driving style of the car. A destabilizing factor of the system is periodic axial compression of the chamber 38 due to aerogravitational overloads of the car wheel.

The presented design of the wheels can also be mounted on the mobile platform of the crushing unit as elements 31 .

The BEG system, as an additional technical means for the establishment and functioning of networks of municipal electric transport (or specialized machines with hybrid power plants) will be rather effective in the process of modernization of the rolling stock of municipal equipment of the waste management system by way of harnessing the potential of secondary energy resources, reducing the amount of required fuels and lubricants (and therefore also the power of exhaust gas from vehicles), and reducing the number of batteries used, for example, during transportation of the proposed crushing equipment.

CONCLUSIONS. Thus, the practical implementation of the presented modifications of the design of the Crushing Unit with Gravity-Pneumatic Actuator for solid waste treatment can significantly increase the environmental and economic efficiency of the operation of the material-technical base of systems for sanitary cleaning of settlements, reducing the specific consumption of necessary electricity, reducing emissions of pollutants, can be used for the modernization and operation of a network of crushing equipment, which will contribute to the achievement of the main objectives of the practical implementation of the National Waste Management Strategy in Ukraine.

\section{REFERENCES}

1. Antonova, T. L. (2017 ), Derzhavna polityka u sferi povodzhennya $z$ vidkhodamy [State policy in the field of waste management]. Actual problems of national jurisprudence. no. 2. pp.134-141, Ukraine.

2. Struchok, V., Mudra, D. (2018), Analiz natsionalnoi stratehii upravlinnia vidkhodamy v Ukraini do 2030 roku shchodo provedennia infrastrukturnykh zakhodiv $z$ pereroblennia tverdykh pobutovykh vidkhodiv [Analysis of the national waste management strategy in Ukraine before 2030 on conducting 
infrastructure measures for the processing of solid domestic wastes]. Materials of the International scientific and technical conference "Fundamental and applied problems of modern technologies" to the 100th anniversary of the foundation of the National Academy of Sciences of Ukraine and to the commemoration of Ivan Puluj (100th anniversary from the day of death) (Tern., 22-24 May 2018), pp. 292-293, Ukrainian.

3. Krasniansky, M. E. (2007), Utylizatsiya ta rekuperatsiya vidkhodiv [Utilization and recovery of waste: Textbook], Kh: Burun and $K, K, K .: K N T, 288$ p.

4. Shmandiy, V. M. (2001), Upravleniye technogennoye bezopasnost'yu urbosistemy na stadii obrazovaniya $i$ postupleniya otkhodov $v$ okruzhayushchuyu sredu [Management of technogenic safety of an urbosystem at forming waste and their supply into the external environment], Monograph, 152 p. (in Ukrainian).

5. Vambol, V. V. (2015), Vybor struktury i parametrov gazokapel'nogo potoka $v$ bloke okhlazhdeniya gaza, poluchennogo pri termicheskoy obrabotke otkhodov [Choice of the structure and parameters of gas-drop flow in the block of cooling gas, received at thermal processing of waste]. Open informational and computer integrated technologies: col. Of sc. Tr. Of Nat. aerocosm. Un-ty, named after N.E. Zhykovsky "Khar. Avia inst",Ed. 67. Kh., pp. 186-196. Ukrainian.

6. Vambol, V. V. (2015), Energeticheskiy analiz usovershenstvovannoy tekhnologii plazmennoy utilizatsii otkhodov [Energetic analysis of the improved technology of plasmic utilization of waste]. Ecological safety, no 2. pp. 63-68. Ukrainian.

7. Parfeniuk, A. S., Antoniuk, S. I., Toporov, A. A. (2002), Al'ternativnoye resheniye problemy tverdykh otkhodov v Ukraine [Alternative solution of the problem of solid waste in Ukraine], Eco-friendly technologies and resource saving. pp. 36-41.

8. Parfeniuk, A. S., Litvinova, T. I., (2016), Perspektivnost' sozdaniya mnogotselevykh biogazovykh kompleksov $v$ Ukraine [Perspective of creation of multipurpose biogas complexes in Ukraine], Donbas 2020: perspectives of development, considered by young scientists: VIII International scientific-practical forum, Donetsk national technical university, Krasnoarmiysk: "DonNTU", pp. 126-128.

9. Popovich, O. R., Zakharko, Y. M., Mailovan, M. S. (2013), Problemy utilizatsii i pererabotki stroitel'nykh otkhodov [Problems of utilization and processing of building waste Theory and practice of building: [collection of scientific works], Ministry of education and science of Ukraine; responsible editor Z.Y. Blikharsky, Lviv : Publishing house of Lviv polytechnics, pp. 321-324, Bulletin National university "Lviv polytechnics", no. 755, Ukrainian.

10. Bakhonina, E. I. (2015), Sovremennyye technologii pererabotki $i$ utilizatsii uglevodorodsoderzhashchikh otkhodov [Modern technologies of processing and utilization of carbohydrate-containing waste], Message 1. Thermal methods of utilization of carbohydrate-containing waste, Bashkir chemical journal, v. 22. no 1. p. 20.
11. Crusher of waste in Ukraine (2018), Electronic resource, URL: https://flagma.ua/drobilka-othodovso220832-1.html (access date: October 06, 2018)

12. Mikhaleva, Z. A., Koptev, A. A., Tarov, V. P. (2002), Metody $i$ oborudovaniye dlya pererabotki sypuchikh materialov $i$ tvordykh otkhodov [Methods and equipment for processing crumbly materials and solid waste], Tambov, Publishing house TSTU, 62 p. Russia.

13. Preparation and processing of raw materials (2010), [Electronic resource] URL: http://ceramis.ru/ index.php?id=55 (access date: October 06, 2018).

14. Grebenchuk, P. S. (2012), Problems of impact crushers operation and possible solutions [Electronic resource] - URL: http://www.rusnauka.com/ 28_NII_2012/Tecnic/3_117733.doc.htm (access date: October 06, 2018).

15. Kutsemelov, B. A. Patent. 2299807 Russia Federation, MPK B29B 17/04, Ustanovka drobleniya shin [Equipment for tires crushing], (Russia, Federation); no. 2005123215; Declared 22.07.2005; Published 27.01.2007, Bull. no. 15.

16. Piddubniak, A. G. Patent 42135 Ukraine, MPK B02C 21/00, B02C23/00, Sistema drobleniya $i$ polucheniya melkodispersnykh materialov [Crushing and finely dispersed materials production system], (Ukraine); no 200900377; Declared 19.01.2009; Published 25.06.2009, Bull. no. 12/

17. Voloshin, O. I. Patent 62683 Ukraine, MPK B02C 13/06, B02C 13/09, Mlyn dlya droblennya materialiv [Mill for crushing materials], (Ukraine); no. 201101511; Declared 10.02.2011; Published 12.09.2011, Bull. no. 17.

18. Slepian, V. Y., Lohinov, I. H. Patent 87351 Ukraine, MPK B02C 13/00, Sposíb udarnogo droblennya [Method of striking crushing], (Ukraine); no. 200708873; Declared 01.08.2007; Published 10.07.2009, Bull. no.13.

19. Seiichi, M. Patent 6481650 United States of America, MPK B02C 1912, "Method and apparatus for crushing waste tires", (United States of America), no 09674804; Declared 07.11.2000, Published 19.112002.

20. Kurt, P. Patent 6481655 United States of America, MPK B02C 1818, "Rotor for crushing", (United States of America), no. 09536602; Declared 28.03.2000, Published 19.11.2002.

21. Zagoratsky, L. P. Patent 2174444 Russia Federation, MPK B02C 2/00. Sposob drobleniya materiala $v$ konusnoy inertsionnoy drobilke [Method of crushing materials in a conic inertial crusher], (Ukraine); no. 99113210; Declared 21.06.1999; Published 10.10.2001, Bull. no. 28.

22. Bondarenko, I. V. Patent 111828 Ukraine, MPK B02C 19/00, F01B 31/00, B26D 3/00, B02C 18/06, [Crushing apparatus with a gravity-pneumatic actuator], (Ukraine); no. 201304265; Declared 05.04.2013; Published 24.06.2016, Bull. no 12.

23. Bondarenko, I. V. Patent 48686 Ukraine: MPK F 03C 99/00, F 03G 3/00. MPA-enerhokolona [MPAenergy column], (Ukreine); no. 200911063; 02.11.2009; Published 25.03.2010, Bull. no. 6. 


\section{И. В. Бондаренко}

\section{МОДЕРНИЗАЦИЯ ОБОРУДОВАНИЯ ДЛЯ ДРОБЛЕНИЯ ТВЕРДЫХ ОТХОДОВ}

Научно-исследовательское учреждение

«Украинский научно-исследовательский институт экологических проблем»

ул. Бакулина, 6, г. Харьков, 61166, Украина. E-mail: i.v.bondarenko@ukr.net

Рассмотрена актуальность проблемы энергосбережения при обработке твердых отходов и проанализирован современный уровень технического обеспечения процессов дробления в сфере обращения с отходами. С учетом основных требований нормативных, отраслевых законодательных актов, принципов и планируемых мероприятий Национальной стратегии управления отходами в Украине, и анализа недостатков известного специального оборудования, предложена принципиально новая конструкция дробильного агрегата с гравитационно-пневматическим электроприводом для использования альтернативных энергоресурсов при эксплуатации необходимого технологического оборудования систем управления вторичным сырьем. Разработанная схема базового аппарата относится к устройствам для дробления ножами, вращающимися и приводящимися в действие силовыми установками объемного вытеснения, может использоваться в системах с образованием значительного количества твердых фракций отходов большой насыпной плотности, дает возможность генерации и аккумуляции необходимой для его работы электроэнергии, используя при этом в качестве приводного усилия вес материалов, которые обрабатываются, что сокращает количество внешнего оборудования, вовлекающегося в процесс переработки. Генерируемая предлагаемым аппаратом энергия может быть накоплена для дальнейшей реализации работы технического обеспечения других стадиях сбора, транспортировки, хранения, утилизации или рекуперации отходов. В работе предусмотрены технологические режимы функционирования и варианты конструкции агрегата для осуществления процессов очистки его рабочих поверхностей и нормализации эксплуатации при аварийных состояниях. С целью повышения уровня энергосбережения транспортировки дробильного оборудования разработана самоходная модификация предложенного дробильного аппарата, используемая выработанную им электроэнергию для питания электродвигателей одиночных или соединенных мобильных платформ при доставке оборудования к месту работы. Изложенные материалы могут быть использованы для повышения эколого-экономической эффективности эксплуатации материально-технической базы схем санитарной очистки населенных пунктов, снижая затраты необходимой электроэнергии, внедрением описанной в работе установки при модернизации сети мобильного дробильного оборудования.

Ключевые слова: отходы, переработка, дробление, энергосбережения, оборудование, очистка.

Стаття надійшла 31.05.2018. 